\title{
Student and Faculty Perspectives of Inclusive Teaching Practices in Teacher Training Degree Programs ${ }^{1}$ \\ Perspectivas de Alunos e Professores de Práticas de Ensino Inclusivas EM Programas de FormaÇÁO de PROFESSORES
}

\author{
Marta SANDOVAL ${ }^{2}$ \\ Carmen MÁRQUEZ VÁZQUEZ ${ }^{3}$ \\ Cecilia SIMON ${ }^{4}$ \\ Alma M. SANDIGO5
}

\begin{abstract}
This study focuses on student and faculty perceptions about inclusive instructional practices in teacher training degree programs in three different universities (two in Spain and one in the USA). We synthetize this framework into four dimensions: (a) identifying students' needs and strengths, (b) accessibility to physical spaces and materials, (c) methodologies and strategies to engage students, and (d) valuing diversity as a resource. A mixed methodology (questionnaire and interviews) was used to collect the information. Six hundred fifty-three university students and 35 faculty from the different education colleges participated in this study. Findings reveal the perceptions of students and faculty regarding both effective practices for diverse inclusive university classrooms as well as barriers to inclusion that affect learning in the participating institutions. Results reflect serious discrepancies between students and faculty members.
\end{abstract}

KEYWORDS: Higher Education. University faculty. College teaching. Universal design. Inclusion.

RESUMO: Este estudo foca as percepções dos alunos e do corpo docente sobre práticas instrucionais inclusivas em programas de formação de professores em três universidades diferentes (duas na Espanha e uma nos EUA). Sintetizamos essa estrutura em quatro dimensões: (a) identificação das necessidades e pontos fortes dos alunos, (b) acessibilidade aos espaços físicos e materiais, (c) metodologias e estratégias para engajar os alunos, e (d) valorização da diversidade como um recurso. Uma metodologia mista (questionário e entrevistas) foi utilizada para coletar as informaçóes. Participaram deste estudo 653 estudantes universitários e 35 professores das diferentes faculdades de educação. Os resultados revelam as percepçóes dos alunos e do corpo docente tanto em relação às práticas efetivas para salas de aula universitárias inclusivas diversas quanto às barreiras à inclusão que afetam a aprendizagem nas instituiçốes participantes. Os resultados refletem sérias discrepâncias entre alunos e docentes.

PALAVRAS-CHAVE: Ensino Superior. Corpo docente da universidade. Ensino universitário. Desenho universal. Inclusão.

\section{INTRODUCTION}

During the last two decades, universities have seen an increase in the enrollment of students from diverse populations, especially from populations that have been historically excluded or marginalized in Higher Education (US Department of Education, 2016). In general, countries around the world have developed systems that create better access to Higher Education to the general population. Yet, minoritized students already participating in Higher

\footnotetext{
${ }^{1}$ https://doi.org/10.1590/1980-54702020v26e0059

${ }^{2}$ Department Development and Educational Psychology, Faculty of Teacher Training and Education, Universidad Autonoma Madrid. Madrid/Spain. E-mail: marta.sandoval@uam.es. ORCID: https://orcid.org/0000-0003-1931-1872

${ }^{3}$ Department Development and Educational Psychology, Faculty of Teacher Training and Education, Universidad Autonoma Madrid. Madrid/Spain. E-mail: carmen.marquez@uam.es. ORCID: https://orcid.org/0000-0003-0708-6698

${ }^{4}$ Department Development and Educational Psychology, Faculty of Psychology, Universidad Autonoma Madrid. Madrid/Spain. E-mail: cecilia.simon@uam.es. ORCID: https://orcid.org/0000-0002-1795-9109

${ }^{5}$ Department Curriculum and Instruction, College of Education, Northern Arizona University Yuma. Arizona/USA. E-mail: alma.sandigo@nau.edu. ORCID: https://orcid.org/0000-0002-6227-8345
} 
Education have expressed feeling devalued or not welcome due to a perceived negative school climate and deficient conditions in the processes of instructional participation (Parker \& Trolian, 2019; Tuero, Cervero, Esteban, \& Bernardo, 2018). This sense of exclusion is worrisome, but more so in colleges of Education where the teaching workforce is being prepared to serve diverse Pre-K-12 students and where the instructional structures used in trainings serve as models of instruction for these pre-service teachers.

Inclusion could be defined as more than a progressive enrollment of groups traditionally excluded from Higher Education (Thomas, 2016). An all-embracing notion of inclusion does not assume that the needs and rights of the individual have been addressed by virtue of their membership of any particular group or groups. Nor does it suggest that individual identity should be lost in the mix of the mainstream culture. It does mean, however, becoming mindful of the individual rights and needs of the 'diversity' of students in Higher Education of today and offering them the best possible learning conditions. As an unending commitment, inclusion requires a continuous application and evaluation of the conditions that promote inclusive practices (Simón et al., 2016).

A basic and useful definition of inclusion in Higher Education has been developed by Hockings (2010): "The instruction that engages students in learning is one that is meaningful, relevant, and accessible to all embracing a vision for each individual and the individual's difference as a source of diversity that enriches the life and learning of everyone" (p. 5). From this perspective, paying attention to student diversity equates to broadening engagement (Jones, 2008; Hockings, 2010), to engage students in self-advocation by providing easily accessible information about services (Grimes, Southgate, Scevak, \& Buchanan, 2019), and to improving teaching strategies that support the inclusion of all students, without exception (Gale, Mills, \& Cross, 2017; Gibson, 2015; O’Shea, Lysaght, Roberts, \& Harwood, 2016).

\section{INCLUSIVE TEACHING STRATEGIES}

Inclusive teaching strategies include the physical arrangement of space within the classroom, the methods and teaching strategies, and evaluations. In other words, these strategies are the actions taken to construct a classroom that runs away from homogeneity. Therefore, the first step faculty must take should lead to knowing their students' readiness to learn, their interests, and their learning profiles, including the learners' preferences, strengths, and challenges. The second step should actively incorporate inclusivity in course development, syllabi, teaching methods, and interactions with students.

Universal Design for learning (UDL) has been found to be a beneficial framework and planning process for educators of all grades to learn and utilize in order to increase educational gains for all students (Rose, Meyer, \& Hitchcock, 2006) In this sense, the University of Guelph undertook a study to develop principles of effective UDL in teaching known as Universal Instructional Design, UID (Palmer \& Caputo, 2002). This model assumes that barriers in education can be reduced, individuals have needs and also capabilities, diversity is a resource, and UID principles benefit all learners - not just those with disabilities (Scott, McGuire, \& Shaw, 2003). The incorporation of Universal Design principles into instructional practices has had a positive impact on student experiences and has also provided rewarding teaching 
experiences for instructors (Kumar, 2010; Kumar \& Wideman, 2014). Framed in the concept of UID, and as other researchers have done in the past, the authors have synthesized inclusive teaching strategies for the purpose of this study (Dallas, Sprong, \& Kluesner, 2016; Gawronski, Kuk, \& Lombardi, 2016; Lombardi, Vukovik, \& Sala-Bars, 2015).

Among the diversity of studies completed within the frame of pedagogy of inclusion, some researchers, including Lombardi et al. (2015), Morgan and Marin (2016), Sniatecki, Perry and Snell (2015) and Takemae, Dobbins and Kurtts (2018), have been interested in analyzing the use of inclusive teaching strategies among faculty in Higher Education. Others, such as Black, Weinberg and Brodwin (2015), Dallas, Sprong and Kluesner (2016) and Kuman and Wideman (2014), have focused on students' perceptions of how these strategies influenced their learning. Our study compares and contrasts the opinions of students and faculty with respect to instructional practices for inclusion, which is a new development.

This study is part of a larger project titled Creating Inclusive University Classrooms: Application of Universal Learning Design in Higher Education, which seeks to understand pedagogical resources available to faculty to build inclusion environments. The current study aims to better understand the differences between how students and faculty perceived instructional practices aimed at diversity and inclusion. To accomplish this, the study analyzed (a) student perspectives in relationship to the application of UID in their teacher preparation courses, and (b) faculty perspectives of their own instructional practices.

\section{Participants}

\subsection{FACULTY MEMBERS}

A total of 35 faculty members from three different teaching preparation programs at three universities were randomly selected and invited to participate in this study. These 35 faculty members met two selection criteria: (1) being full-time professors, and (2) teaching faceto-face undergraduate education courses related to the areas of inclusive or special education and instruction for diverse students. From these 35 invited faculty members, 26 members (19 women and 7 men) participated in this study agreeing to be interviewed. They belonged to 8 US university, 6 Complutense university and 12 Autonoma university (Spain). They all had over 8 years of teaching experience.

\subsection{STUDENTS}

Students were invited to respond to the student questionnaire. A total of 653 students from the Colleges of Education at the three institutions in the U.S. and Spain volunteered to participate in the online questionnaire. Of the 653 students, (582 women and 71 men) 204 were from Autonoma university (Spain), 110 from Complutense university (Spain), and 332 from Northern Arizona University. Out of all participating students, $48.8 \%$ were enrolled in Early Childhood programs, $43.9 \%$ in Elementary and Special Education programs, and $7.4 \%$ in Physical Education programs. From all students, $20.7 \%$ were considered to be at the Freshman level, $20.6 \%$ at a Sophomore level, $21.8 \%$ at a Junior level, and 37\% as Seniors. 
All three Colleges of Education are state Universities. Complutense and Autonoma are located in Madrid (Spain), and NAU is located in the Southwest of the United States. They are all universities that identify with the values of inclusion. The Spanish university have over 2500 education undergraduate students in each. In contrast, the College of Education at NAU, a university, serves approximately 600 Education undergraduate students. This international platform offered unique opportunities of dialogue and understanding of common interests that enriched the outcomes of the study.

\section{Methods}

Data for this study was collected through a questionnaire for students and a semistructured interview for faculty. The questionnaire and the interviews were designed ad hoc to address UID principles within four dimensions: (1) identification of needs and strengths, (2) accessibility to physical spaces and resources, (3) methodologies for engagement, and (4) diversity as a resource. Table 1 shows the dimensions, the indicators that define them, as well as the questionnaire items and the interview questions that collect them.

The student questionnaire included 27 items. Of these items, 26 used a Likert rating system, with response values of 0 (never) to 5 (always). The remaining item was an open-ended question. Because translation was used in developing the tools of this study, questions used for the structured interview were validated by experts in the field according to the relevance and clarity of each item. The student questionnaire was also validated through a pilot study completed after the initial investigation. Twenty-five students provided feedback on the clarity and purpose of each item. A fidelity analysis for internal consistency had an acceptable reliability coefficient of Cronbach value of 0.708 . This feedback may be used to adjust and refine a final instrument.

\begin{tabular}{llll}
\hline \multicolumn{1}{c}{ Dimensions } & $\begin{array}{c}\text { Description Faculty members//stu- } \\
\text { dents perceptions }\end{array}$ & $\begin{array}{l}\text { Items in Inter- } \\
\text { view to Faculty }\end{array}$ & $\begin{array}{c}\text { Items in Question- } \\
\text { naire to Students }\end{array}$ \\
\hline $\begin{array}{l}\text { Identification and } \\
\text { analysis of students } \\
\text { needs }\end{array}$ & $\begin{array}{l}\text { Strategies and actions perceived by } \\
\text { students to know the learning needs } \\
\text { of students// strategies. }\end{array}$ & $2,3,6,9$ & $16,17,20,22,23,24$ \\
$\begin{array}{l}\text { Accessibility to phy- } \\
\text { sical spaces and class } \\
\text { resources and materials }\end{array}$ & $\begin{array}{l}\text { Accommodations of content and eval- } \\
\text { uation as consideration of students } \\
\text { learning pacing / Accommodations } \\
\text { perceived by students. }\end{array}$ & $1,4,7,8$ & $1,2,3,4,5,6,7,8$, \\
$\begin{array}{l}\text { Strategies and metho- } \\
\text { dologies for student } \\
\text { engagement }\end{array}$ & $\begin{array}{l}\text { Strategies and activities to engage } \\
\text { students in the learning/ engagement } \\
\text { strategies perceived by students. }\end{array}$ & $5,11,12,13$ & $9,10,11,12,14,19,21$, \\
& $\begin{array}{l}\text { Faculties actions that demonstrate di- } \\
\text { versity as an instructional and cultural } \\
\text { resource // Possibilities it offers for } \\
\text { participation within the class }\end{array}$ & 14,15 & $18,23,25,26$ \\
\hline Diversity as a resource & & \\
\hline
\end{tabular}

Table 1. Universal Instructional Design (UID) dimensions.

Source: Elaborated by the authors. 
Data that reflected faculty perception of their own practices included a semi-structured interview using an ad-hoc protocol with 15 questions related to faculty's inclusive instructional practices. The interview questions were based on knowledge, designs, and pedagogical practices for inclusion. This protocol was piloted for validation with 12 non-participant faculty members. The feedback received during the pilot use of the protocol was considered and incorporated into the interview protocol to add clarity and procure consistent understanding of each of the 15 questions of the instrument. The semi-structured interviews with faculty members were conducted individually. Each of these interviews was 45-69 minutes long. All participating faculty members were given an Institutional Review Board (IRB) Informed Consent form that delineated the study's objectives, expectations, and procedures for collection and storage of data.

\section{Data analysis}

\subsection{FaCUlTy INTERVIEW}

Interviews were recorded and then transcribed for analysis. Faculty responses were analyzed according to established procedures described by Creswell (2013) for reducing and coding data and verifying conclusions. A structural analysis of content was carried out following the proposed process of Miles and Huberman (1994). This process resulted in the inductive obtaining of a system of categories and codes that underpinned its analysis.

\subsection{STUDENT QUESTIONNAIRE}

The paper and pencil questionnaire were administered in person by the researchers to all participating students. The researchers ensured that the faculty teaching the course where the questionnaire was being administered was absent from the classroom at the time of completion, and that such faculty had no role in the distribution or collection of the questionnaire. Before inviting students to fill out the questionnaire, they were given 10 minutes to read the informed consent approval required by our institutions. Students were informed of the objective of the investigation, the anonymity of their personal identifiers, and the procedures for handling the data.

To analyze the collected data from the questionnaire, a descriptive statistic of the variables of the study reflected in the three dimensions used in the questionnaire was conducted. Frequency tables were used to analyze the absolute frequency of values with a confidence range of $95 \%$ for both independent groups. This descriptive statistic of variables was conducted using the software IBM SPSS 20.

\section{Results}

The results from both the questionnaire of students and the faculty interviews are described in a narrative format and organized in the four UID dimensions: (1) identifying needs and strengths of students, (2) accessibility to physical spaces and materials, (3) methodologies and strategies to engage students, and (4) valuing diversity as a resource. 


\subsection{IDENTIFYing STUdents NEEDS AND STRENGTHS}

The first dimension, identifying needs of students, includes six themes or relevant faculty practices. Culturally competent faculty: (a) know names of students, (b) collect student information relevant to his or her achievements, (c) model behaviors that support intercultural development, (d) take into account religious practices, (e) treat all students equally, and (f) are approachable and accessible (Table 2).

\begin{tabular}{lcccccc}
\hline \multicolumn{1}{c}{ Items } & \multicolumn{7}{c}{ Results (\%) } \\
\hline & Never & Rarely & Sometimes & $\begin{array}{c}\text { Many } \\
\text { Times }\end{array}$ & Always & NS/C \\
\hline Knows names of students & 10.6 & 16.1 & 18.4 & 18.7 & 31.7 & 4.4 \\
Collects relevant information of students & 21.2 & 18.3 & 16.9 & 16.7 & 19.9 & 7.1 \\
Demonstrates interests in students' cultures & 7.5 & 14.7 & 20.1 & 22.7 & 23.2 & 11.8 \\
Demonstrates considerations of religious practices & 20.6 & 10.7 & 9.4 & 9.4 & 13.0 & 37.0 \\
Gives equal attention to all students & 6.9 & 15.8 & 25.9 & 24.4 & 24.8 & 2.1 \\
Is available and approachable & 1.7 & 10.7 & 30.4 & 27.1 & 23.0 & 7.1 \\
\hline
\end{tabular}

Table 2. Identifying student needs.

Source: Elaborated by the authors.

The student questionnaire responses revealed that professors never $(10.6 \%)$ or rarely (16.1\%) knew their names. Students also believed (21.2\%) that professors never allotted time to purposefully engage with students to obtain students' personal information that may affect their academic achievement. Also, $7.5 \%$ of students suggested that professors never considered any cultural aspects that may directly affect students' participation in class. The percentage of students suggesting that professors never consider religious aspects was even greater $(20.6 \%)$. Considering student responses, about $20 \%$ of students perceived that their professors did not identify their needs through the suggested practices. About half of the students felt their professors treated all students equally, many times (24.4) or always (24.8). Also, half of them declared that their professors were accessible and approachable many times (27.1) or always (23).

In contrast, interviews with faculty revealed that most professors agreed on the need to collect information on students' needs. Professors also recognized the necessity to structure procedures that provide details about the specific needs and circumstances that may affect students' learning. In general, the faculty assessed themselves favorably in this dimension. However, the data generally showed that few faculty members structured procedures and activities with the intention of getting to know their students. It also revealed that such activities only happened during the first day of class or when a student requested tutoring or support outside of class. These two contexts were the most common opportunities where faculty learned the most detailed information about the students. 
When collecting information on the needs of students, most of the faculty members were not particularly systematic, and they tended not to create tools for this purpose: "There is a digital platform for students to communicate any challenges they may face in class, but very few students make use of this platform" (Faculty Participant 12); "I informally ask if anyone has a need and if so, I offer tutoring, so I learn about his or her needs and adjust my instruction" (Faculty Participant 6). Some professors also pointed out gaining information on the needs of the students through student work products or class artifacts.

\subsection{ACCESSIBILITY TO PHYSICAL SPACES AND MATERIALS}

In the access to physical spaces and materials, seven themes were included: (a) accessible lectures, (b) subtitled audiovisuals, (c) various formats for materials, (d) resources posted online, (e) tools which are easy to use and handle, (f) adequate spaces, (g) safe physical learning environments (Table 3).

\begin{tabular}{|c|c|c|c|c|c|c|}
\hline \multirow[t]{2}{*}{ Items } & \multicolumn{6}{|c|}{ Results (\%) } \\
\hline & Never & Rarely & Sometimes & $\begin{array}{l}\text { Many } \\
\text { Times }\end{array}$ & Always & $\mathrm{NS} / \mathrm{C}$ \\
\hline Access to lectures & 0.3 & 4.3 & 20.9 & 40.6 & 32.5 & 1.4 \\
\hline Audiovisuals are subtitled & 14.3 & 26.4 & 26.1 & 13.8 & 12.7 & 6.7 \\
\hline Materials are presented in different formats & 2.6 & 13.3 & 26.8 & 35.4 & 21.3 & 0.5 \\
\hline $\begin{array}{l}\text { Additional materials are available online for } \\
\text { reinforcement }\end{array}$ & 1.1 & 7.7 & 28.1 & 40.2 & 22.7 & 0.3 \\
\hline Equipment is easy to use & 1.1 & 2.8 & 12.3 & 38.2 & 41.1 & 4.6 \\
\hline Physical spaces are adequate & 4.6 & 7.2 & 12.3 & 31.7 & 43.6 & 0.6 \\
\hline College facilities are a safe environment & 0.8 & 4.8 & 16.7 & 34.7 & 42.2 & 0.9 \\
\hline
\end{tabular}

Table 3. Practices that facilitate accessibility of physical spaces, and resources and materials. Source: Elaborated by the authors.

According to student responses, they believed their professors made efforts to present content in various ways and made materials accessible to students online. However, students claimed that their professors never $(14.3 \%)$ or rarely $(26.4 \%)$ used subtitles in audiovisuals to reinforce or expand course concepts.

When evaluating access to the physical environments of universities, some students claimed that classrooms, libraries, laboratories, and other university facilities where students are required to be are never $(4.6 \%)$ or rarely $(7.2 \%)$ accessible to their physical needs. The data showed that the institutions are accessible to most students; however, only $41.1 \%$ stated that they have never experienced limitations to the physical environment of the university facilities. These results may reflect student responses on feeling safe and being in an environment 
conducive to learning. Students responded that they rarely $(4.8 \%)$ or sometimes $(16.7 \%)$ felt safe and in an environment conducive to learning.

Meanwhile, interviews with faculty members indicate, in a general manner, that professors did not question the accessibility of materials used in class. They did not see inaccessibility for students with special needs as a problem, but they did not lack the intention to meet accessibility requirements:

I don't believe that the activities I used in class have been obstacles for students. Students would have complained about it, if so (Faculty Participant 16).

I don't believe students find it difficult to access the class material. The material used in class is simple ... usually, books are accessible in our library and through online platform). Students don't have issues accessing the class materials unless they do not have Internet at home or a classmate that may provide them when students miss class (Faculty Participant 15).

However, participating professors recognized that the current accessibility to materials presents a barrier if a student with a visual or audiovisual disability were participating in their courses. They would provide special audiovisual resources for such students. Professors recognized that audiovisual tools used in class as resources for learning are hardly ever subtitled, reflecting a technological deficiency that may be a problem for some students. In some situations, professors have contacted disability support services to meet this need.

In summary, faculty members did not have specific structures to guarantee access to materials. Rather, they offered support to students in response to disabilities known or visible to them. Few professors stated they presented class materials in different formats with the purpose of providing access to the curriculum for all students. These actions were perceived as acts of goodwill or experience rather than lack of responsibility. Thus, their responses may be reactive rather than proactive.

Regarding the physical barriers that limit access to the physical spaces of the classroom and to participation in class activities, the findings indicate that some professors recognized physical barriers while others did not believe they exist.

In addition to physical barriers, some obstacles to virtual learning were also noted. All participating universities used digital platforms, where material that was required, complementary, or optional was uploaded. In some situations, faculty recognized possible barriers to accessing these platforms and the uploaded materials. As this professor says, "I have seen documents uploaded on the on-line platform and these are copies of the original documents with very poor resolution" (Faculty Participant 17).

\subsection{Methodologies and STRATEgIES TO ENGAGE STUDENTS}

The dimension of effective instructional methodologies used to serve diverse students included eight themes: (a) present concepts relevant to the objective, (b) emphasize essential concepts, (c) pause to clarify or explain concepts; (d) use heterogeneous grouping; (e) provide detailed syllabi, (f) adjust content to students' needs, (g) allow sufficient time for testing, and (h) use multiple types of assessments (Table 4). 


\begin{tabular}{lcccccc}
\hline \multicolumn{1}{c}{ Items } & \multicolumn{5}{c}{ Results \% } \\
\hline & Never & Rarely & Sometimes & ManyTimes & Always & NS/C \\
Present core concepts & 15.3 & 24.8 & 20.9 & 19.2 & 18.4 & 1.4 \\
Place emphasis on key concepts & 1.7 & 15.5 & 30.2 & 23.6 & 28.7 & 0.3 \\
Pauses during lecture & 4.6 & 15.5 & 29.9 & 27.3 & 22.1 & 0.6 \\
Uses heterogeneous grouping & 16.0 & 16.0 & 17.3 & 19.0 & 18.3 & 13.5 \\
Provides informational guides & 4.9 & 9.0 & 19.8 & 21.3 & 29.9 & 15.0 \\
Adjust content to diversity of students & 1.7 & 5.7 & 30.7 & 34 & 27.8 & 0.2 \\
Provides sufficient time during testing & 1.7 & 4.8 & 17.5 & 37.4 & 33.3 & 5.4 \\
Uses multiple forms of evaluation & 3.1 & 9.5 & 21.5 & 33.0 & 32.4 & 0.3 \\
\hline
\end{tabular}

Table 4. Methodologies used by faculty to serve diversity of students. Source: Elaborated by the authors.

Questionnaire data reflected that university faculty members continue to use traditional lecture methodologies. Some students reported that their instructors never present key ideas in order to clarify lectures $(15.3 \%)$ or content comprehension $(24.8 \%)$. Students also specified that rarely $(15.3 \%)$ or sometimes $(30.2 \%)$ do professors emphasize key concepts relevant to the objective of the lesson. Furthermore, student perspectives on faculty practice was that instructors were more concerned about the presentation of content rather than on pausing to ensure that students understood the content. Only 22.1\% of participating students believed that their professors always adjust the pace of instruction. Correspondingly, 16.6\% responded that never or rarely is the classroom organized to facilitate work in heterogeneous groups.

Regarding evaluation of learning, the results showed that very few faculty collected differentiated evaluation forms; only $32.4 \%$ of students answered positively to this. It seems that more time was allotted to taking tests than to catering to student needs. In a similar manner, it is especially interesting to know how the professors perceived diversity, as well as strategies and practices utilized to create a more inclusive environment for all students. In this sense, interviewed faculty made reference to three aspects: adjustments of explanations, creation of heterogeneous workgroups, and evaluation methods.

Only a few professors attributed a significant importance to heterogeneous group work in the classroom as a support resource for all students. They recognized the difficulty in promoting more cooperative work dynamics in the classroom. As this professor says, "I try to adjust as much as possible; for instance, I propose to them that if they have difficulties presenting to the class, that we talk and look for other ways to present the content, such as smaller groups" (Faculty Participant 11).

However, professors recognized that barriers perceived by their students must be overcome. 
Students have difficulties entering a group because the groups are closed off and students choose the student who performs the best. This practice is so usual in the classroom that it imposes a barrier, since the competitiveness generated by this practice generates many more problems (Faculty Participant 21).

According to another teacher, "each group member has a defined role, and roles are always rotated. Students prefer to pick their own groups and it upsets them when we group them with students that are not of their preference (Faculty Participant 12).

Nevertheless, facing these barriers is as important as developing other competencies and values beyond those linked to the grade of a particular activity, or working with diverse classmates.

Next year, what I will do is explicitly let them know why I do it, as I have seen a change in attitude when I explicitly state the reason why it is done and they understand the reason why it must be done: "I do not do it because I want to throw you off, but because you are working on other skills." For example, there is a case of the group, which had an [culturally and linguistically] student that needed more time, or needed modifications to better understand the text. There were students that said, "Would I be required to study the summary made by this student?" but after telling them that yes, they would be working with him, and (even though he was learning to write) I explained that it was a cooperative learning activity and he would work with the best students of other groups and have all the information they needed, they then would say, "Let's do it, then." (Faculty Participant 20).

The responses of students and faculty to adjusting the content and activities to the learning pace of students point to the use of some strategies for all students with the purpose of addressing this principle in a generalized manner. Professors wished to meet the specific needs of linguistically diverse students. The faculty expressed a concern for providing equal academic access to this group of students. They recognized that to facilitate the completion of assignments or to engage linguistically diverse students in activities, they must make some instructional accommodations.

Regarding the process of evaluation, participating faculty stated that they utilize a variety of forms to know and learn about their students. They point out that the evaluations are standardized for all students, although some faculties made accommodations and modifications for culturally and linguistically diverse students or students with disabilities.

The test has been given using language "of books" with shorter phrases ... it contains the same information but it is presented with simpler language for [linguistically diverse] students. I allow them to use a dictionary during testing and if they have doubts about the language, I clarify for them (Faculty Participant 12).

As one teacher points out: "In my evaluations I avoid penalizing students for their learning styles and give the option of testing orally or in writing" (Faculty Participant 2). Another teacher mentions: "I ensure that the written and audiovisual material will be accessible to students. They can present their work in any form they prefer" (Faculty Participant 24). 


\subsection{Diversity as A RESOURCE}

This last dimension, valuing diversity as a resource, included five inclusive practices: (a) use students' personal experiences to exemplify concepts, (b) connect learning to students' personal experiences, (c) structure opportunities for diverse and non-diverse students as well as students with disabilities and students without disabilities to collaborate, (d) develop intercultural competences, and (e) encourage self-expression (Table 5).

\begin{tabular}{|c|c|c|c|c|c|c|}
\hline \multirow[t]{2}{*}{ Items } & \multicolumn{6}{|c|}{ Results (\%) } \\
\hline & Never & Rarely & Sometimes & Many Times & Always & $\mathrm{NS} / \mathrm{C}$ \\
\hline $\begin{array}{l}\text { Uses students' personal experiences to } \\
\text { exemplify concepts }\end{array}$ & 4.9 & 15.0 & 26.7 & 25.9 & 21.8 & 5.7 \\
\hline $\begin{array}{l}\text { Connects learning to students' personal } \\
\text { experiences }\end{array}$ & 2.0 & 13.2 & 30.7 & 26.4 & 25.6 & 2.1 \\
\hline $\begin{array}{l}\text { Structures opportunities for mainstream } \\
\text { and non-mainstream students to colla- } \\
\text { borate }\end{array}$ & 9.7 & 14.9 & 13.3 & 13.3 & 10.3 & 38.5 \\
\hline Develops intercultural competences & 2.9 & 10.4 & 25.5 & 29.3 & 26.2 & 5.7 \\
\hline Encourage self-expression & 1.4 & 4.8 & 18.9 & 33.4 & 40.6 & 0.9 \\
\hline
\end{tabular}

Table 5. Valuing diversity as a resource.

Source: Elaborated by the authors.

Instructional practices that build on the background knowledge of the students include using student experiences when giving examples, providing opportunities so students can make connections between new concepts and their personal lives, and structuring opportunities to develop intercultural competencies. Students believed that rarely (15\%) or sometimes $(26.7 \%)$, professors included relevant student experiences as examples during instruction or provided opportunities to make personal connections with the concepts taught. Similarly, students stated that their professors never $(9.7 \%)$ or rarely $(13.2 \%)$ paired native speakers with non-native speaker students. These limitations created barriers in developing intercultural competencies for all students. On the contrary, the students stated that many times $(34.4 \%)$ or always $(40,6)$ they will feel free to express their opinions in class.

The professorate provided limited information on how students' background knowledge was used to build their instruction. The few who did mention such practices believed that building instruction on the students' background knowledge enhanced opportunities for expression and created a more integrated and rich instruction.

The activities used in class are linked to multiple intelligence (composing a song, painting a mural, writing a reflection). They have the choice of using their creativity as they like, but most groups of students use more than one expression (Faculty Participant 8).

Yes... because we want students to relate theory to their personal experiences. For instance, having a German student in our class has allowed us to make comparisons on concepts we are teaching and understand what parts of the concepts are similar between Germany and Spain. In this situation, having her in class has been an asset. It has allowed us to have other cultural 
views; it has allowed us to reflect on how accessible our materials are from a language perspective (Faculty Participant 19).

The majority of professors recognized that they did not structure opportunities to develop intercultural competencies in the classroom. They recognized that they did not view diversity as a class resource and thus, belittle the value of intercultural competencies. However, a few professors recognized the need to develop intercultural competencies as a tool to make teaching more comprehensible.

In all honesty, I do not give enough attention [to cultural competencies] as I should. I believe that the busyness of everyday life does not allow you to stop and reflect and work more diligently to better serve different backgrounds culturally students (Faculty Participant 11).

Another teacher points out, "I have tried to develop [intercultural competencies] in the past. It was not something structured, but I did take advantage of diverse students to enrich all students participating in that class. However, we should do more in a purposeful way" (Faculty Participant 15).

A final factor highlighted in interviews by some faculty members is the importance of creating a classroom climate of safety, acceptance, and support, where all students are able to participate. Many professors recognized the challenges they face in creating a positive climate in their classrooms. They also recognized the need of bettering this aspect of teaching. The faculty identified a high student-teacher ratio, lack of resources and materials, and scarce professional development in addressing diverse students as the major barriers for creating a positive classroom environment: "The greatest limitation in engaging all students with equity in the classroom is the student-teacher ratio, the limitations of resources, and the lack of knowledge among professors [in regard to languages and religion]" (Faculty Participant 15); "There is no initiative to provide professional development for faculty in these issues. This limits the attention given to diversity in the student body" (Faculty Participant 7).

Even though the faculty members recognized limitations in creating a safe and conducive learning environment, they also recognized the influence of student empathy and collaborative attitude shaped by the needs of all students.

\begin{abstract}
We have spoken little about how we teach and how we should teach concepts in our instruction. This creates a great disparity in the instructional practices among professors, resulting in confusion for students. Some professors are more direct, more talkative in their explanations and evaluate regularly. Others favor individual work, reflection, and take advantage of in-person instruction as a space of instructional enrichment (Faculty Participant 22).
\end{abstract}

\title{
7 Conclusions
}

The findings of this study have important implications for the role faculty members, their pedagogy, and the content and the interactions play in shaping an inclusive classroom environment. The evidence of this study points to a mismatch between students and their teachers. Yet, to this dissonance, the designed response anticipated is that of finding to respond to the needs of students and minimized the risk of failure in the class (Ainscough, Stewart, Colthorpe, \& Zimbardi, 2018). As such, the results of this study serve to describe inclusion as 
a process rather than to draw dichotomous conclusions about the existence or non-existence of inclusion in the classroom.

The significant difference in responses between students and faculty indicate ample opportunities to increase inclusive practices. Professors should be concerned about identifying the needs of students with greater consistency and in a systematic manner. These practices are foundational to begin planning and maintaining inclusive practices that are student centered. Purposefully structuring activities to collect information from students throughout the course and not only at the beginning or when the student is in need of intervention is a proactive practice. It requires actively reaching out to students rather than passively waiting for students to self-advocate. Structuring activities to elicit more information that can facilitate student learning also requires actions that demonstrate the understanding that cognitive and physical factors, whether visible or not, affect learning as do social and cultural ones.

This study has implications for improving teaching explanations. In this sense, it highlights the need to put subtitles to the audiovisual presentations and to propose activities that reinforce or extend the contents. Furthermore, it also has implications for the creation of heterogeneous working groups and for the further adjustment of evaluation methods.

Furthermore, and in agreement with the findings of other researchers such as Kumar and Wideman (2014) and Dallas, Sprong and Kluesner (2016), the results of this study describe opportunities to minimize physical and virtual barriers to learning. Student responses stated an overall lack of access to physical environments, resources, and materials. This issue constitutes, without a doubt, a vital element to advance inclusion in higher education. The presence, participation, and achievement of all students require effective use of physical and virtual spaces, open platforms for diverse voices, and goals that affect the overall quality of life (UNESCO, 2016). In fact, merging technology and the Universal Design framework will be an avenue to meeting the learning needs and wants of $21^{\text {st }}$ century students (Finnegan, 2018). These outcomes dictate proactive and preventive responses to include identifying needs of students, giving access to physical and virtual resources, using methodologies and strategies that engage all students, and valuing diversity as a resource.

Regarding limitations, the purpose of this study was to create an understanding of the differences in perceptions between faculty and students with regards to instructional practices for inclusion in institutions located in two different countries. However, the authors recognize that the influences of each country's social and political histories should be considered if further understanding of unique contexts for each participating university is desired. Since the purpose of this study was to understand general differences of perspectives for inclusion between faculty and students, no differentiation on the social and political histories of the involved countries were made.

Even though the recommended changes in instructional practice from this study relate directly to university classrooms for teacher preparation programs, they provide firstperson experiences in designing and organizing instruction as a system that may also be useful in meeting the needs of diverse students in Pre-K-12 classrooms. For this to happen, the faculties member needs support, professional development that allows for positive transformation in their practices framed in pedagogy of inclusion, and constant critical reflection upon 
the diversity present in its classrooms (Dallas, Sprong, \& Kluesner, 2016; Moriña, 2017), especially if the views of students are taken into account, which can be a lever for change in the professional development of faculties.

\section{REFERENCES}

Ainscough, L., Stewart, E., Colthorpe, K., \& Zimbardi, K. (2018). Learning hindrances and selfregulated learning strategies reported by undergraduate students: identifying characteristics of resilient students. Studies in Higher Education, 43(12), 2194-2209.

Black, R. D., Weinberg, L. A., \& Brodwin, M. G. (2015). Universal design for learning and instruction: Perspectives of students with disabilities in higher education. Exceptionality Education International, 25(2), 1-16.

Creswell, J. W. (2013). Qualitative inquiry and research design: Choosing among five approaches. Thousand Oaks, CA: SAGE Publications, Inc.

Dallas, B., Sprong, M., \& Kluesner, B. (2016). Multiuniversity comparison of faculty attitudes and use of universal design instructional techniques. Rehabilitation research policy and education, 30(2), 148-160.

Finnegan, L. A. (2018). The impact of technology on the teaching and learning process. In V. C. Bryan, A. T. Musgrove, \& J. R. Powers (Eds.), Handbook of research on human development in the digital age (pp. 235-257). Hershey, PA: IGI Publishing/IGI Global.

Gale, T., Mills, C., \& Cross, R. (2017). Socially inclusive teaching: Belief, design, action as pedagogic work. Journal of Teacher Education, 68(3), 345-356.

Gawronski, M., Kuk, L., \& Lombardi, A. R. (2016). Inclusive instruction: Perceptions of community college faculty and students pertaining to Universal Design. Journal of Postsecondary Education and Disability, 29(4), 331-347.

Gibson, S. (2015). When rights are not enough: What is? Moving towards new pedagogy for inclusive education within UK universities. International Journal of Inclusive Education, 19(8), 875-886.

Grimes, S., Southgate, E., Scevak, J., \& Buchanan, R. (2019). University student perspectives on institutional non-disclosure of disability and learning challenges: reasons for staying invisible. International Journalof Inclusive Education, 23(6), 639-655. DOI: 10.1080/13603116.2018.1442507

Hockings, C. (2010). Inclusive learning and teaching in higher education: a synthesis of research. Higher Education Academy.

Jones, R. (2008). New to widening participation? an overview of research. York: Higher Education Academy.

Kumar, K. (2010). A journey towards creating an inclusive classroom: How universal design for learning has transformed my teaching. Transformative Dialogues: Teaching and Learning Journal, 4(2), 1-5.

Kumar, K. L., \& Wideman, M. (2014). Accessible by design: Applying UDL principles in a first year undergraduate course. Canadian Journal of Higher Education, 44(1), 125-147.

Lombardi, A., Vukovik, B., \& Sala-Bars, I. (2015). International comparisons of inclusive instruction among college faculty in Spain, Canada and United States. Journal of Postsecondary Education and Disability, 28(4), 447-460.

Miles, M. B., \& Huberman, A. M. (1994). Qualitative data analysis. An expanded sourcebook. Thousand Oaks: Sage Publications. 
Morgan, M., \& Marin, P. (2016). Teaching diversity in the graduate classroom: the instructor, the students, the classroom or all of the above. Journal of Diversity in Higher Education, 9(2), 143-157.

Moriña, A. (2017). Inclusive education in higher education: Challenges and opportunities. European Journal of Special Needs Education, 32(1), 3-17. DOI: 10.1080/08856257.2016.1254964

O'Shea, S., Lysaght, P., Roberts, J., \& Harwood, V. (2016). Shifting the blame in higher educationsocial inclusion and deficit discourses. Higher Education Research and Development, 35(2), 322-336.

Palmer, J., \& Caputo, A. (2002). The Universal Instructional Design implementation guide. Retrieved on April 14, 2020 from http://www.cer.jhu.edu

Parker, E. T., \& Trolian, T. L. (2019). Student Perceptions of the Climate for Diversity: The Role of Student-Faculty Interactions. Journal of Diversity in Higher Education. Advance online publication. DOI: http://dx.doi.org/10.1037/dhe0000132

Rose, D., Meyer, A., \& Hitchcock, C. (2005). The universally designed classroom: Accessible curriculum and digital technologies. Cambridge, MA: Harvard Education Press.

Scott, S. S., McGuire, J. M., \& Shaw, S. F. (2003). Universal design for instruction: A new paradigm for adult instruction in postsecondary education. Remedial and Special Education, 24(6), 369-379.

Simón, C., Echeita, G., Sandoval, M., Moreno, A., Marquez, C., Fernandez, M. L., \& Perez, E. (2016). De las adaptaciones curriculares al diseño universal para el aprendizaje y la instrucción: un cambio de perspectiva. Congreso Madrid Sin Barreras.

Sniatecki, J., Perry, H. B., \& Snell, L. H. (2015). Faculty attitudes and knowledge regarding college students and disabilities. Journal of Postsecondary Education and Disability, 28(3), 259-275.

Takemae, N., Dobbins, N., \& Kurtts, S. (2018). Preparation and experiences for implementation teacher candidates perceptions and understanding of UDL. Issue in teacher education, 27(1), 73-93.

Thomas, L. (2016). Developing inclusive learning to improve the engagement, belonging, retention, and success of students from diverse groups. In M. Shah, A. Bennett, \& E. Southgate (ed.), Widening Higher Education Participation (pp. 135-159). Oxford: Elsevier.

Tuero, E., Cervero, A., Esteban, M., \& Bernardo, A. (2018). ¿Por qué abandonan los alumnos universitarios? Variables de influencia en el planteamiento y consolidación del abandono. Educación $X X 1,21(2), 131-154$.

US Department of Education (2016). Office of Planning, Evaluation and Policy Development and Office of the Under Secretary. Advancing diversity and inclusion in higher education. Washington, D.C.: U.S. Department of Education.

UNESCO and International Bureau of Education (IBE) (2016). Training tools for curriculum development. Reaching out to all learners: A resource pack supporting inclusive education. Geneva: IB.

Received on: 16/03/2020

Reformulated on: 06/04/2020

Approved on: 07/07/2020 
SANDOVA, M. et al. 